\title{
Alveolar soft part sarcoma presenting with back pain
}

\author{
Amari T Thompson, Samuel J Ford, Anant Desai, David Gourevitch
}

Midland Abdominal \&

Retroperitoneal Sarcoma Unit, Queen Elizabeth Hospital Birmingham, Birmingham, UK

\section{Correspondence to} Dr Amari T Thompson, amari.thompson@doctors. org.uk

\section{Accepted 3 April 2017}

\section{DESCRIPTION}

A 35-year-old man was referred to the Sarcoma service with a 2-year history of worsening back pain, left-sided radicular pain and a mass on CT scan. In the 6 months following the onset of the back pain, he developed progressive numbness and paraesthesia in the L2 dermatome. This was worse on standing. On clinical examination, power was unaffected but somewhat limited by pain. No 'red flag' symptoms were present (table 1). The CT scan demonstrated a large retroperitoneal mass on the left with invasion into the L2 vertebra (figure 1 and 2) and bilateral pulmonary metastases. USS-guided biopsy revealed high grade alveolar soft part sarcoma. He was started on palliative radiotherapy (30 Gy and 10 fractions) and given six cycles of doxorubicin and ifosfamide. Imaging at 8 months postdiagnosis has indicated stable disease.

\begin{tabular}{|c|c|c|}
\hline $\begin{array}{l}\text { Sphincter and gait } \\
\text { disturbance }\end{array}$ & Saddle anaesthesia & $\begin{array}{l}\text { Severe or } \\
\text { progressive } \\
\text { motor loss }\end{array}$ \\
\hline $\begin{array}{l}\text { Widespread } \\
\text { neurological deficit }\end{array}$ & Age $<20$ or $>55$ years & $\begin{array}{l}\text { Previous } \\
\text { malignancy }\end{array}$ \\
\hline Systemic illness & $\begin{array}{l}\text { Human } \\
\text { inmmunodeficiency } \\
\text { virus }\end{array}$ & Weight loss \\
\hline Intravenous drug use & Steroid use & Structural deformity \\
\hline $\begin{array}{l}\text { Non-mechanical pain } \\
\text { (no relief with bed } \\
\text { rest) }\end{array}$ & Fever & Thoracic pain \\
\hline
\end{tabular}

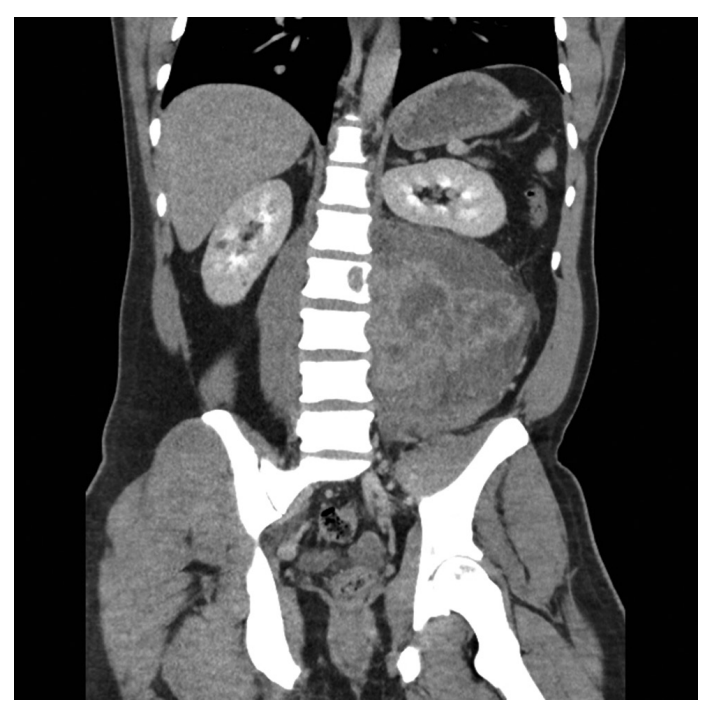

Figure 1 Tumour causing erosive destruction of the left lateral aspect of the $\mathrm{L} 2$ vertebrae.

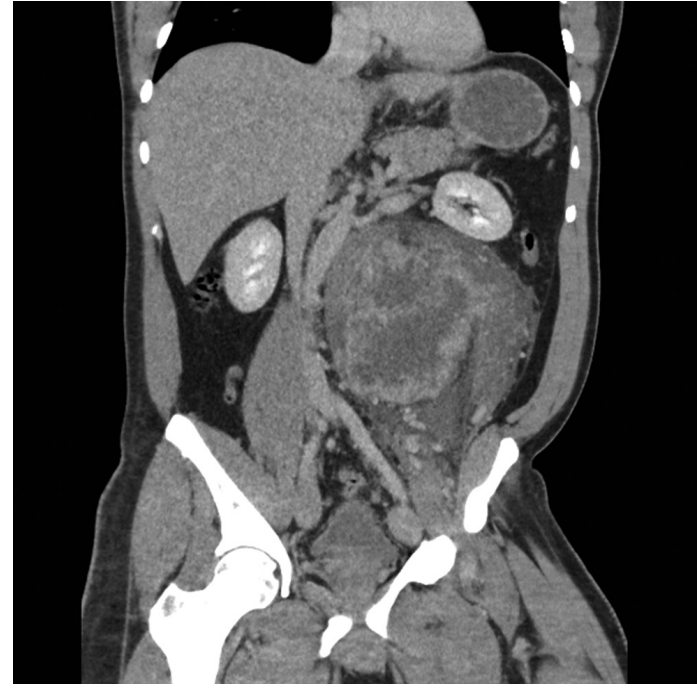

Figure $216.4 \times 12.4 \times 19.4 \mathrm{~cm}$ mass with central necrosis, closely related to the left psoas muscle.

Alveolar soft part sarcoma is a very rare condition, believed to account for $<1 \%$ of all soft tissue tumours. ${ }^{1}$ Diagnosis is made by a combination of histology and immunohistochemistry; looking for strong nuclear expression of transcription factor 3 . $^{1}$ Patients are typically young and present with metastases.

Complete wide surgical excision by a sarcoma surgeon is advised in cases where the disease remains localised. Recurrence following complete excision is rare, but metastases may still occur years later. $^{2}$ In patients with localised disease survival rates of $60 \%$ at 5 years and $38 \%$ at 10 years have been documented. ${ }^{2}$ Chemoradiotherapy for metastatic disease has been documented in the literature, with limited success.

\section{Learning points}

- This unfortunate case serves to remind us that despite the absence of 'red flag' symptoms, clinical suspicion should be raised in the presence of progressively worsening symptoms over a short duration.

Contributors ATT and SJF drafted the article, which was edited for submission by AD. The patient was admitted under and reviewed by DG who suggested submission.

Competing interests None declared.

Patient consent Obtained.

Provenance and peer review Not commissioned; externally peer reviewed. 
(c) BMJ Publishing Group Ltd (unless otherwise stated in the text of the article) 2017. All rights reserved. No commercial use is permitted unless otherwise expressly granted.

\section{REFERENCES}

1. Folpe AL, Deyrup AT. Alveolar soft-part sarcoma: a review and update. J Clin Pathol 2006;59:1127-32.
2. Lieberman PH, Brennan MF, Kimmel M, et al. Alveolar soft-part sarcoma. A clinicopathologic study of half a century. Cancer $1989 ; 63: 1-13$.

3. Reichardt $P$, Lindner T, Pink $D$, et al. Chemotherapy in alveolar soft part sarcomas. what do we know? Eur J Cancer 2003:39:1511-6.

4. The Royal College of Radiologists. Acute back pain with potentially serious (red flag) features. iRefer: making the best use of clinical radiology. London: The Royal College of Radiologists, 2012. http://irefer.org.uk/images/pdfs/msk_m05_abstract.pdf.

Copyright 2017 BMJ Publishing Group. All rights reserved. For permission to reuse any of this content visit http://group.bmj.com/group/rights-licensing/permissions.

BMJ Case Report Fellows may re-use this article for personal use and teaching without any further permission.

Become a Fellow of BMJ Case Reports today and you can:

- Submit as many cases as you like

- Enjoy fast sympathetic peer review and rapid publication of accepted articles

- Access all the published articles

Re-use any of the published material for personal use and teaching without further permission

For information on Institutional Fellowships contact consortiasales@bmjgroup.com

Visit casereports.bmj.com for more articles like this and to become a Fellow 